\title{
ANALYSIS ON RELATIONSHIP AMONG DENDROBIUM spp BALI BASED ON CHARACTERISTICS OF LEAVES ANATOMY
}

\author{
Ida Ayu Putri Darmawati ${ }^{{ }^{*}}$, I Nyoman Rai ${ }^{1}$, Rindang Dwiyani ${ }^{1}$, and \\ Ida Ayu Astarini ${ }^{2}$ \\ ${ }^{1}$ Agroecotechnology Study Program, Faculty of Agriculture Udayana University. \\ ${ }^{2}$ Biology Department, Udayana University \\ *Corresponding author: darmawati@unud.ac.id
}

\begin{abstract}
From explorations in several parts of the forest of Bali, 24 species of Dendrobium orchids were identified. Relationship among these species needed to be mapped for further development of orchids. Characteristics of leaves anatomy have been used to determine relations among plants. Characteristics of anatomy that were observed in this study from the paradermal and transversal cut of the leaves were shape and number of epidermis cells, location of stomata, the direction of stomata opening, shape and number of stomata, length of the epidermis and stomata, density of stomata, index of stomata, and thickness of mesophyll. Analysis of relations among species was displayed as a dendogram, using the software Minitab 17 Vis. Analysis of relationship among 24 species of Dendrobium Bali based on the leaves anatomy used grouped average method in squared Euclidean distance with the scale of 0.349 to 0.972 . At Euclidean distance of 0.349 , two clusters were formed where D. aloifolium and D. subulatum were separated from the other clusters. At $80 \%$ similarity coefficient, seven clusters were formed using similar method, with the $3^{\text {rd }}$ and $5^{\text {th }}$ clusters had the shortest distance (169.35). If species that were clustered together were cross-bred, the success rate was higher; meanwhile, the further away the relation between species, the smaller the success rate of cross breeding. The possibility of getting high-quality genotypes was higher when the cross-breeding was successful.
\end{abstract}

Keywords: relationship between orchid species, Dendrobium spp Bali, characteristics of leaf anatomy

\section{INTRODUCTION}

Dendrobium is a type of orchid that has high genetic variety, with counts for about 275 species among 1600 species of orchids in the world (Gandawidjaya and Sastrapraja, 1980; De et al., 2015). Its spread pattern starts from coastal area to mountainous area. An exploration done in several forest areas in Bali found 24 species of Dendrobium orchids (Darmawati et al., submitted). Relationship among these orchid species needed to be mapped for further development of orchids, with one of the mapping methods was through observation of leaf anatomy characteristics.

Characteristics of leaf anatomy have been used in many studies to determine relationship among plants (Yulia and Juliarni 2007; Rompas et al., 2011; Hafiz et. al., 2013). Leaf anatomy characteristics that became the object of the current study were 
internal structure of plants such as leaves. Leaf anatomy consists of the internal structure of a leaf, such as shape, type, structure, and number of cells. Several anatomy characteristics could be used in taxonomy classification as stated by Fahn (1991).

Leaves are one of the organs that get direct impact from the environment, especially radiation of the sunlight. Sunlight is used by the leaves for photosynthesis process. The environmental conditions such as salinity and sunlight radiation, are responded by the plants and shown in the form of adaptation either morphologically of anatomically. According to Hidayat (1995), leaves are highly varied organs, both morphologically and anatomically. Therefore, a study on the anatomy of leaves of Dendrobium spp was needed in its spread area in Bali. This study was aimed to explore the relationships among Dendrobium spp Bali, through observation of leaf anatomy characteristics in order to improve the database for plant identification for the purpose of plant breeding.

\section{MATERIALS AND METHODS}

\section{Materials and equipment}

Materials used in the study were leaf samples collected from 24 species of Dendrobium found in Bali (D. acuminatisimum, D. aloifolium, D. aphylum,
D. arcuatum, D. conspicum, D. cruminatum, D. fimbriatum, D. heterocarpum, D. inflatum, D. lineariforium, D. macrophylum, D. plicatyle, D. rugosum, D. salacsense, D. scundum, Dendrobium sp Sepang, Dendrobium sp Wanagiri, D. spathylingue, D. stuposum, D. stuartii, D. subulatum, D. spurium, D. tetraedre and D. truncatum). Chemicals used were $70 \%$ ethanol and Safranin dye $0.25 \%$. Equipments used were light microscope, Optilab, laptop, object glass, cover glass, Pasteur pipette, cutter, label sticker, Erlenmeyer flask, and digital camera.

\section{Research Methodology}

This study used descriptive research to describe and interpret the structure of the epidermis, stomata, and mesophyll of the leaves of Dendrobium spp Bali, based on the method developed by Woelaningsih 1984; Hidayat and Suradinata, 1990; and Rompas et al., 2011. The steps performed are as follows:

1. Sampling was performed at morning time in the private collection garden and samples were then put in a cool box containing ice before they were transported to the laboratory.

2. Fully developed leaves were used as samples and cut longitudinally at the upper and lower parts of the leaves as 
well as transversally in order to observe the mesophyll part of the leaves.

3. Each cut was put on the object glass and added with drops of water. A drop of $0.25 \%$ of Safranin dye was added to help the observation. Samples was then covered with the cover glass and observed under the microscope at $100 \mathrm{x}$ and 400x magnifications.

4. Microscope was connected with Optilab after getting a clear image and magnification was adjusted to $268 \mathrm{x}$ magnification. Next, the image was captured using Optilab and the results were observed directly on a laptop screen.

\section{Observation}

The structure of epidermis and stomata was observed from an angle at $268 \mathrm{x}$ magnification. The variables that were observed were seen from the paradermal cut of the leaves of Dendrobium spp. Bali including: shape and number of stomata, the length of epidermis and stomata (measurement of complete epidermis and stomata was done on the longitudinal cut of the leaves using the software Optilab Image Raster with $\mu \mathrm{m}$ as the measurement unit), density of stomata, and stomata index. Density of stomata was counted based on the number of stomata per observation are $(0.25$ $\mathrm{x} 0.25 \mathrm{~mm}^{2}$ ), while stomata index was collected by calculating the number of stomata per total number of stomata added with the number of epidermis and multiplied with 100. Observation of the transversal cut of the leaves was on the thickness of the mesophyll by using the application Optilab Image Raster $(\mu \mathrm{m})$.

\section{Data analysis}

Data collected were analyzed with descriptive analysis by drawing and interpreting the structure of epidermis and stomata of the leaves. In order to know the relationship among species, dendogram was prepared where quantitative data were averaged and analyzed using the software Minitab 17 Vis.

\section{RESULTS AND DISCUSSION}

\section{Leaf Anatomy Characteristics of}

\section{Dendrobium spp Bali}

In general, the shape of leaf epidermis of 24 species of Dendrobium spp found in Bali was similar; there were long leaves, pentagons, hexagons, and irregulars, with length ranged between 16.15 to $58.96 \mu \mathrm{m}$ with the number of epidermis ranged between 26.33 - 130.00 cells/observation area. Even though there were differences in terms of shape of epidermis, ontogenetically, the epidermis was uniform. The structure of the epidermis was neatly arranged linearly, with strong structure morphologically and anatomically since it consisted of 
highly-dense cells with almost no rooms between cells.

Leaf stomata of the 24 species of Dendrobium found in Bali was surrounded by four neighboring cells, two parallel neighboring cells on each slide on the right and left, and two neighboring cells located at the end of each axis. The number and structure of neighboring cells were determined by the species of the plant (Salisbury and Ross, 1995). In leaves with parallel veins, stomata were structured in long lines and formation of stomata was started from the end to the base of the leaves or basipetal (Hidayat, 1995). Location of stomata was mostly at the bottom part of the leaf surface (abaxial), except in $D$. macrophylum, D. plicatyle, and D. rugosum on both sides of the leaves (amphistomaty). Direction of the cell opening of the stomata was parallel with the neighboring cells, except on D. aphylum, D. macrophylum, D. rugosum, D. scundum and D. spathylingue, was observed vertically.
Overall, the stomata of the leaves of Dendrobium spp Bali shaped like a kidney and it was categorized as anomocytic as in dicotyledonous plants. This result showed that not all monocotyledon plants had halter-shaped stomata. The stomata was observed in a closed position, except in $D$. rugosum whose stomata opened at day and night times, as observed from the open pores (Fig. 1). Stomata open when the cover cells collect water and expand (Salisbury and Ross 1995). Increase or decrease of the size of the pores of the cover cells is due to the change in the turgor pressure in the cover cells (Fahn 1991). Pores among cover cells were formed due to the crack of the cell membrane (Kartasapoetra 1988). The number of stomata could be observed in Dendrobium spp varied in the observation area, with the highest average number of stomata was found in $D$. salacsense (18.33), while the least number was found in D. aloifolium and D. subulatum (1.67) with irregular distance between stomata.

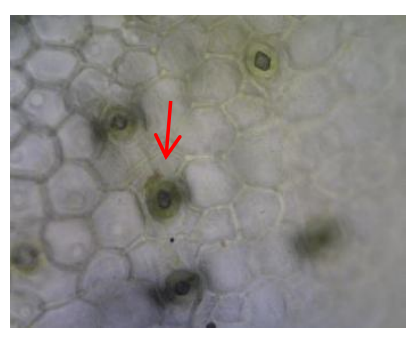

Fig. 1. Structure of epidermis and stomata of the leaves of D. rugosum

Stomata density is an important et al., 2007). The leaves of Dendrobium spp character that affects gas exchange (Pandey Bali that were observed had a density ranging 
between 35.088 - 385.965, with the highest density was found in D. salaccense. Dendrobium that was classified as Grastidium $(D$

and

D acuminatisimum) tended to have high stomata density. The value of stomata density is affected by the size of stomata, where the smaller the stomata, the higher the density (Willmer, 1983). According to Howard, 2006, size of stomata is affected by the leaf thickens; the thicker a leaf is, the bigger the size of its stomata. This phenomenon was observed in the leaves of $D$. aloifolium and $D$. subulatum (Fig. 2). Stomata density affects the leaf ability to tolerate lack of water. Leaves with high stomata density can survive better in the condition of water scarcity (Sun et al., 2014).

Stomata index of 24 species of Dendrobium observed were ranging from 1.98 - 13.93, with the highest value was found in $D$. aphylum, while the lowest value was found in D. subulatum. Stomata index shows the ratio between the number of stomata with the total number of stomata and epidermis. The index is related with the change of the area of stomata and epidermis.
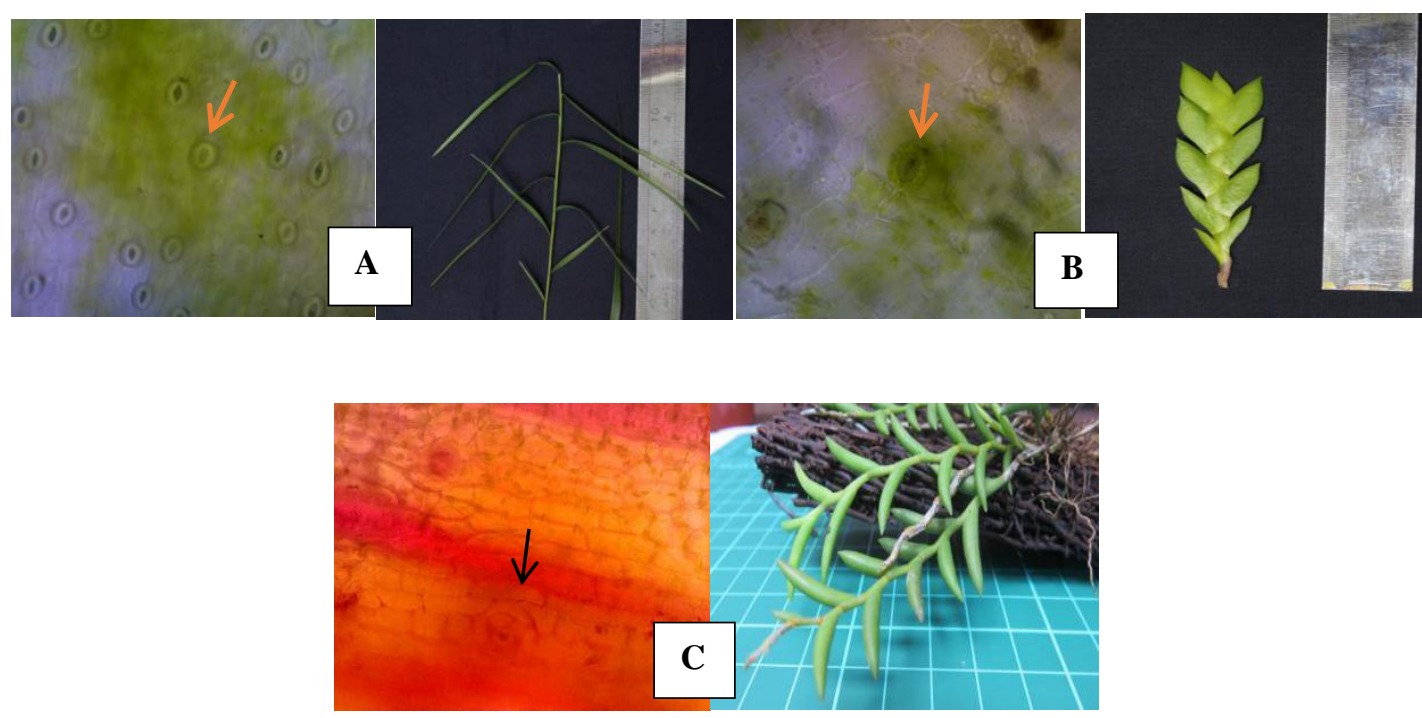

Fig. 2. Density of stomata and leaf thickness of D.salacsense (A),D.aloifolium (B) and D. subulatum (C).

Relationship among Dendrobium spp Bali

Results of relationship analysis among 24 species of Dendrobium Bali based on the leaf anatomy characters using grouped average of squared Euclidean distance of
0.349 to 0.972 . At the distance of 0.349 or $34.9 \%$ similarity, two clusters were formed as shown in Fig. 3. Based on these clusters, D. aloifolium and D. subulatum were separated from the other clusters. This 
phenomenon shows that both Dendrobiums had the furthest relationship with other clusters.

At $80 \%$ similarity, seven clusters were formed using similar method, where the $3^{\text {rd }}$ and the $5^{\text {th }}$ cluster had the closest distance (169.35). The $3^{\text {rd }}$ cluster consisted of two species (D. aphylum and D. cruminatum) with the characteristic variable of thickness of leaf mesophyll $(\mathrm{SD}=45.9)$. While the $5^{\text {th }}$ cluster had six species in it $(D$. macrophylum, D. plicatile, D. rugosum, $D$. spurium, $D$. stuartii, and $D$. truncatum) with similar characteristic variable $(\mathrm{SD}=55.2)$.
More similarity in the anatomy characteristics of the orchids observed showed closer relationships, while less similarity showed further relationship (Sokal and Sneath, 1963). Based on this relationship analysis, in terms of plant breeding, species located in similar cluster had higher success rate in cross breeding, while the further the relationship between species, the smaller the success rate of cross breeding, and the possibility of getting genotypes with high quality could be higher when the cross breeding was successful.

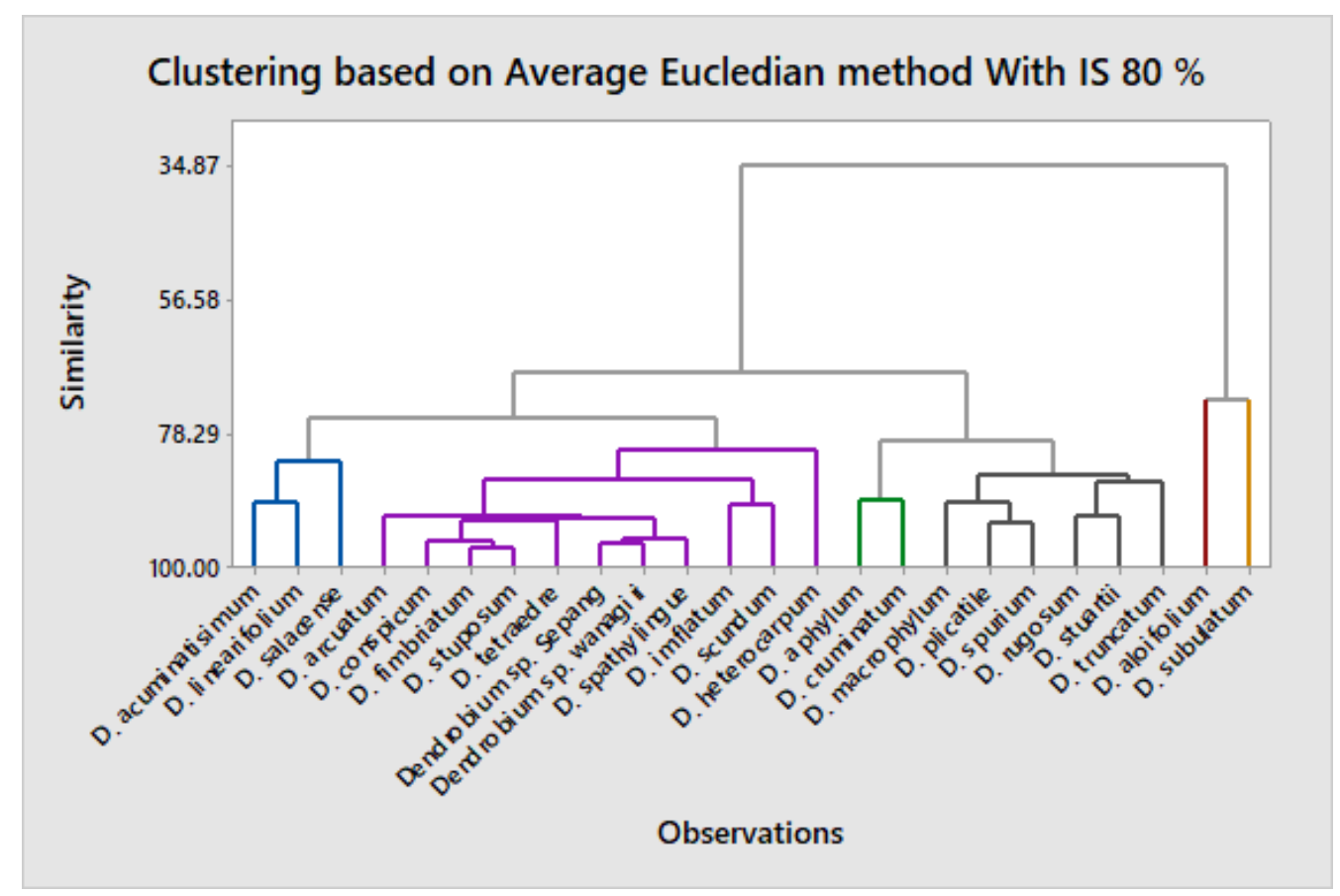

Fig. 3. Dendogram of Dendrobium spp Bali with average Euclidean distance linkage of similarity index $80 \%$

\section{ACKNOWLEDGEMENT}

The authors would like to thanks the Head of Bali Capital Investment and
Licensing Agency, Coordinator and KPH of Central Bali, and Head of Conservation Center of Eka Karya Bali Botanical Gardens for permission given to explore some areas of 
the Balinese forest. The authors also thank the

Exploration Team (Gede Tirta, Aninda and

Dhika), as well as all those who have helped during the research activities.

\section{REFERENCES}

De LC, Rao AN,. Rajeeva PK, and Srivastava. M. 2015. Morphologycal Characterization in Dendrobium spescies. Journal of Biosciences. 4(1):1198-1215.

Fahn, A. 1991. Anatomi Tumbuhan. Ed ke-3. Penerjemah: Soediarto

A, Koesoemaningrat R.M.T., Natasaputra M, Akmal H; Editor Tjitrosomo S.S. Yogyakarta: Universitas Gajah Mada Pr. Terjemahan dari: Plant Anatomy

Gandawidjaya D. dan Sastrapradja. S. 1980. Plasma nutfah Dendrobium asal Indonesia. Bull. Kebun Raya 4(4): 113-125.

Hafiz, P., Dorly, dan S. Rahayu. 2013. Karakteristik Anatomi Daun Dari Sepuluh Spesies Hoya Sukulen Serta Analisis Hubungan Kekerabatannya. Buletin Kebun Raya 16(1): 58 - 73

Hidayat, E.B, dan Suradinata, T. S. 1990. Penuntun praktikum anatomi tumbuhan. F-MIPA ITB, Bandung.

Hidayat, E.B. 1995. Anatomi Tumbuhan Berbiji. Bandung: ITB Pr.

Howard, P. W. 2006. The Dendrobiums. A. R. G. Gantner Verlag K. G. pp. 833

Kartasapoetra, A. G. 1988. Pengantar anatomi tumbuh-tumbuhan (tentang sel dan jaringan). Bina Aksara, Jakarta

Pandey, R., P.M. Chacko, M.L. Choudhary, K.V. Prasad and M. Pal, 2007. Higher than optimum temperature under $\mathrm{CO} 2$ enrichment influences stomata anatomical characters in rose (Rosa hybrida). Scientia Horticulturae 113:74-81.
Rompas, Y., H. L. Rampe, dan M. J. Rumondor. 2011. Struktur Sel Epidermis dan Stomata Daun Beberapa Tumbuhan Suku Orchidaceae. J. Bioslogos. 1 (1): 13-19

Salisbury, F.B. and C.W. Ross, 1995. Fisiologi Tumbuhan. Ed. Ke-4. Lukman DR, Sumaryono, penerjemah; Niksolihin S, editor. Bandung: Penerbit ITB.

Sokal, R.H and P.A. Sneath, 1963. Principle of Numerical Taxonomy. W.H. Freeman and Co. San Francisco. pp 291-303.

Sun, M.,Yang, S. J., Zhang, J. L., Bartlett, M., and Zhang, S.B. 2014. Correlated evolution in traits influencing leaf water balance in Dendrobium (Orchidaceae). Plant Ecol. 215, 1255-1267.doi:10.1007/s11258-014-0 383-2.

Willmer, C.M. 1983. Stomata. London: Longman Group limited.

Woelaningsih. 1984. Penuntun Praktikum Botani Dasar. Laboratorium Anatomi Tumbuhan Fakultas Biologi UGM, Yogyakarta

Yulia, N. D., dan Juliarni. 2007. Paraphalaenopsis laycockii (M. R. Henderson) A. D. Hawkes: Tinjauan Terhadap Morfologi Tanaman dan Anatomi Daun. Buletin Kebun Raya Indonesia 10 (2): 47 - 52. 